\title{
EDITORIAL
}

\section{Education, Emigration, Ethnicity and African-Australians}

\author{
Tanya Lyons \\ Editor, Australasian Review of African Studies \\ President, African Studies Association of Australasia and the Pacific \\ School of History and International Relations, Flinders University \\ Research Fellow, Centre for Africa Studies, \\ University of the Free State, South Africa \\ editor@afsaap.org.au
}

In this issue of ARAS we deal with the important issues of education, emigration, ethnicity, the perception and representations of, and the challenges and opportunities experienced by African-Australians. In a global collaboration of scholars, the first article explores the involvement of parents in the education of their children in Northern Uganda. Betty Akullu Ezati, Cornelius Ssempala and Peter Ssenkusu from Makerere University, Jody McBrien from the University of South Florida, and Jan Stewart from the University of Winnipeg have all presented their research conducted between 2007 and 2015 in Northern Uganda in their article entitled Parents, Pay Attention! Factors Related to Parental Involvement with Education in Northern Uganda. What is striking about their original research is that the findings have lessons for all involved in the education of children. The fact that Uganda's civil wars, and in particular the impact of the Lord's Resistance Army in Northern Uganda, and subsequent insecurity has 'disrupted' many aspects of people's daily lives, is investigated by these authors in terms of the resilience of communities in educating their next generations. Although, they found that parents have reduced their involvement in children's education, the reasons for this are complex, but are integrally linked to the consequences of war, and also post-conflict government policies. Ezati et al use an 'ecological approach' to ask in what ways academic achievement might be enhanced overall, and provide some useful recommendations on how to improve parental involvement in their children's education. Lessons for us all! 
One of the many traumatic consequences of war is forced migration. Fleeing your home to search for somewhere else to settle is an all too common scenario in the world today with over 65 million people forcibly displaced or as refugees. Australia has welcomed many refugees and migrants from African countries over the years, and scholars David Lucas and Barbara Edgar from the Australian National University have provided us with ongoing statistical analyses of these migrations and settlements (for example see Lucas, Jamali \& Edgar, 2011; Lucas, 2008a; Lucas, 2008b). In this latest instalment, Zimbabwe's Emigrants: Growth and Change in Australia, Edgar and Lucas examine the growth and change in emigration from Zimbabwe to Australia. What is interesting about their findings is that between 2001-2006 the number of emigrants from Zimbabwe doubled, making them the "second most numerous birthplace group from SubSaharan Africa" in Australia. These demographers also examine the ancestry of these increasing numbers of immigrants from Zimbabwe, and demonstrate that there has been a shift from predominately 'white European' to 'black-African' migrants. Edgar and Lucas provide a fascinating account of the history of migration from Southern Rhodesia, then Rhodesia, then Zimbabwe to Australia and account for the 'push factors' affecting this shift in demographics and migration over time.

For the African-Australian community, whether settled through the humanitarian schemes as refugees, or welcomed as skilled-migrants, as many from Zimbabwe have been, a number of ongoing challenges face them on a daily basis. Danielle Horyniak and Megan Lim from Monash University, and Peter Higgs from both Monash and La Trobe Universities, have conducted important research into the representations of AfricanAustralians in Australia's news media reporting. The title of their article News Media Reporting on Substance Use Among People of African Ethnicity in Three Australian States, 2003-2013, indicates that they have chosen to specifically look at the issue of 'substance use' such as alcohol and illicit drugs, which have increasingly been "identified as an emerging health concern" within these communities, and correspondingly of increasing interest to the media. Their research reveals that in particular, the Victorian press compared to other Australian states, has more coverage of these issues. Significantly, these media representations are contributing to the 'alienation and othering' of African communities in Australia, especially through the "failure to acknowledge the socio-political and cultural diversity of African communities." The authors provide some important recommendations for the media, in particular to train journalists in ethnic diversity and awareness of different cultural groups, and to 
basically stop focussing on the ethnic origins of the person when discussing other factors, such as substance use.

Continuing this theme of the representations of African-Australians, but shifting the focus from popular media to more serious academic literature, Naduni Wickramaarachchi and Edgar Burns from La Trobe University have reviewed the publications on South-Sudanese migrants in refereed journals. This research is based on the authors concerns that 'compartmentalised' and so-called Fields of Research (FoR) basically limit the availability of relevant research to respective researchers and service providers. They argue that the wide spectrum of research which has been conducted on this community of former-refugees must be available and "accessible in a crossreferenced platform to better serve southern Sudanese migrants' needs”. Wickramaarachchi and Burns demonstrate six multidisciplinary themes which have emerged from the research publications, and these include the psycho-social; adaptation and acculturation; families and health; education; the media and legal system; and community development. By bringing this literature together here in their review they have revealed a number of gaps in the research including those relating to economic activities and issues for the elderly.

Wickramaarachchi and Burns have tapped directly into the purpose of the Australasian Review of African Studies (ARAS), to be 'that multidisciplinary platform' for research on African studies, and AfricanAustralian issues and research. Indeed, this journal has been publishing articles on this topic for a number of years, and, as a multidisciplinary journal, often gets overlooked by scholars searching for discipline specific research. For the record (editor's prerogative), I cite here the other articles published in the back-issues of ARAS that relate to the African diaspora in Australia, but have not been cited by Wickramaarachchi and Burns, whose focus was on the specific South-Sudanese diaspora research and publications, hence these articles may have missed their key word searches. Clearly however, these articles will have some relevance for other future researchers examining similar issues (see Ndhlovu, 2015; Hebbani \& Preece, 2015; Lawson, 2014; O’Byrne, 2014; Warsame, Mortensen \& Janif, 2014; Harte, 2013; Muchoki, 2013; Muchoki, 2012; Oliver, 2012; Harris, 2012; Deng \& Pienaar, 2011; Marete, 2011; Saffu, 2010; Wakholi, 2010; Dhanji, 2010; Matereke, 2009; Kifle, 2009; Mapulanga-Hulston, 2009; Correa-Velez and Onsando, 2009; Zwangobani, 2008; Kifle \& Kler, 2008; Bitew, Ferguson \& Dixon, 2008; Arfish and Olliff, 2008; Robinson, 2008; and Dimock, 2008). In particular, this last reference to Liz Dimock's 2008 Bibliography of Africans in Australia, provides an important and additional list of sources, references and publications on this significant issue prior to 
2008. Dimock (2008) should really be one of the first ports of call for any researcher investigating the African-Diaspora in Australia.

Another article that can be added to Wickramaarachchi and Burns' ongoing analysis, is published below by William Arbur and Ramón Spaaij, both from Victoria University, and the latter also based at the University of Amsterdam. These two authors have prepared an important report on the employment experiences of the South Sudanese community in Melbourne, Australia. Their article is particularly concerned with the barriers to employment, such as negative discrimination, among this cohort of former refugees, and how this effects their attempts at settlement in Australia. Arbur conducted interviews for this research and the voices of the participants are important for all researchers and settlement service providers to hear.

The final article in this issue of ARAS is an interesting and personal reflection from Eugen Bacon, based at Swinburne University of Technology. Bacon uses narrative strategies to explore trauma, and engages with autoethnography to express her emotional journey in navigating the different worlds that African-Australian migrants necessarily exist within. Entitled Narrative and Narrative Strategies to Explore Trauma: 'Up Close from Afar' - An African Migrant's Story, Bacon critically reflects on her own creative fiction exploring life and death, and questions her own African-Australian identity. This is a unique article and makes an interesting contribution to the pages of $A R A S$.

\section{Bibliography}

Arfish, H.M. and Olliff, L. (2008) Dialogue - 'It's Difficult to Stay, and it's Hard to Leave': Stories of Refugee Journeys in Australia -, Australasian Review of African Studies. 29 (1\&2),104-109

Bitew, G., Ferguson, P. and Dixon, M. (2008) Ethiopian-Australian Students' Experience of Secondary Schooling in the Australian Education System in the State of Victoria. Australasian Review of African Studies. 29 (1\&2), 78-91

Correa-Velez, I. and Onsando, G. (2009). Educational and Occupational Outcomes Amongst African Men From Refugee Backgrounds Living in Urban and Regional Southeast Queensland. Australasian Review of African Studies. 30(2), 114-128

Deng. S. A. and Pienaar, F. (2011) Positive Parenting: Integrating Sudanese traditions and New Zealand styles of parenting. An Evaluation of Strategies with Kids - Information for Parents (SKIP) Australasian Review of African Studies 32(2),160-179 
Dhanji, S. (2010). Social or Unsocial? The Linkage Between Accommodation, Health and Well-Being Among Former Horn of Africa and Sudanese Refugees Living in Australia, Australasian Review of African Studies. 31(1), 106-136

Dimock, L. (2008). Bibliography - Africans in Australia. Australasian Review of African Studies. 29 (1\&2), 133-154

Harris, A. (2012). Culture is our Future: The Constitutive Role of African Australian film. Australasian Review of African Studies. 33(2), 178200

Harte, W. (2013) Towards a culturally-appropriate model of collecting demographic data from ethnic minority communities: A case study of the Burundian community census in Queensland. Australasian Review of African Studies. 34(1), 82-102

Hebbani, A. and Preece, M. (2015) Spoken English does matter: Findings from an exploratory study to identify predictors of employment among African refugees in Brisbane. Australasian Review of African Studies, 36(2) December, 110-129

Kifle, T. (2009) Far from home but altruistic in nature: Evidence from ritrean-born People in Australia. Australasian Review of African Studies 30(2), 86-97

Kifle. T. and Kler, P. (2008) The Financial Satisfaction of African Immigrants in Australia. - Australasian Review of African Studies 29(1\&2), 66-77,

Lawson, L. (2014) 'I have to be my own mother and father': the African Student Experience at University, a Case Study Using Narrative Analysis, Australasian Review of African Studies. 35 (1), 59-75

Lucas, D. (2008a) Statistics - Africans in the Australian Census. Australasian Review of African Studies. 29 (1\&2), 110-112

Lucas, D. Jamali, M. and Edgar, B. (2011) The Sudan-born in Australia: a Statistical Profile, Australasian Review of African Studies. 32(2),1024.

Lucas, D. Statistics - Africans in New Zealand (2008b), Australasian Review of African Studies. 29 (1\&2), 113-118

Mapulanga-Hulston, J. (2009) The Migration of Health Professionals in Sub-Saharan African Countries and the Impact on People's Right to Health. Australasian Review of African Studies. 30(2), 98-113

Marete , J. (2011) The Settlers' Dream: Resettlement Experiences of Sudanese Refugees in New Zealand. Australasian Review of African Studies. 32(2), 180-193 
Matereke, K. (2009) 'Embracing the Aussie Identity': Theoretical Reflections on Challenges and Prospects for African-Australian Youths, Australasian Review of African Studies. 30(1), 129-143

Muchoki, S. (2012) Sexuality and Sexual Health of African-Australian Men with Refugee Backgrounds from the Horn of Africa: The Need for a New Research Agenda. Australasian Review of African Studies. 33(1), 132-150

Muchoki, S. (2013) '[In Australia] what comes first are the women, then children, cats, dogs, followed by men': Exploring accounts of gender relations by men from the Horn of Africa. Australasian Review of African Studies. 34(2), 78-98

Ndhlovu, F. (2015) Marginality and Linguistic Cartographies of African Denizens as Spheres of Possibility in Regional Australia, Australasian Review of African Studies. 36(1), 7-28

O’Byrne, R. (2014) - Narratives of Return Among Refugee-Background South Sudanese in New Zealand. Australasian Review of African Studies. 35(1),76-94,

Oliver, M. (2012). Standing Up, Reaching Out and Letting Go: Experiences of Resilience and School Engagement for African High Schoolers From Refugee Backgrounds. Australasian Review of African Studies 33(1), 151-164

Robinson, J.A. (2008) Review Article - Health, Adjustment and Well-Being in the African Diaspora: Trends in Research December 2007 to June 2008. Australasian Review of African Studies, 29 (1\&2), 119-132

Saffu, S. A. (2010). Adult education and community capacity building: The case of African-Australian women in the Northern Territory Australasian Review of African Studies. 31(1), 13-36,

Wakholi, P.M. (2010). African Cultural Education and Schooling: towards Bicultural Competence of African Australian Youth. Australasian Review of African Studies. 31(1), 82-105

Warsame, M., Mortensen, A. \& Janif, J. (2014). Improving Educational Achievement for Students From Somali Backgrounds in Auckland, New Zealand: An Evaluation of a School Catch-Up Programme -, Australasian Review of African Studies Volume 35 Number 2, 25-44

Zwangobani, K. (2008) From Diaspora to Multiculture: in Search of a Youthful Pan-African Identity, Australasian Review of African Studies, 29 (1\&2), 51-65 